\title{
Should Christian Global Health Be Distinctive?
}

\section{A Reflection}

\section{Raymond Downing ${ }^{a}$}

${ }^{a}$ Senior Lecturer, Department of Family Medicine, Moi University School of Medicine, Kenya

\begin{abstract}
Christian global health is often seen as the overlap of global health activities with Christian motivations, sometimes including evangelism. But is there anything distinctive about Christian global health? Drawing on the insights of Jacques Ellul, this article proposes how Christian global health could be qualitatively different from humanitarian global health.
\end{abstract}

In December 2014, Time Magazine chose "The Ebola Fighters" for its Person of the Year cover story. And while they wisely chose to highlight African as well as Western global health workers, most of whom did not get infected by the virus, it was three American medical missionaries who did get infected that made the story so compelling. Christian global health workers had suddenly become celebrities. But did they do anything special, anything uniquely Christian? Many who shared the Ebola Fighters' honor were from humanitarian organizations like the Red Cross and Médecins Sans Frontières (MSF), not Christian missions.

The motivational indistinctness in the Ebola fighters' story is worth pondering and provides a very contemporary example for us to ask: Is there a distinctive Christian approach to global health, or do we simply draw from the myriad approaches already described, testing each piece for how well it reflects general Christian principles? Christian Ebola fighters had experiences very parallel to humanitarian fighters. Is Christian global health then simply a matter of finding the overlap of the Venn diagrams of global, health, and Christian?

This seems to have been the approach since Christians first became involved in global health over 200 years ago. Early medical missionaries, while often passionately evangelistic, built the medical side of their ministry squarely on the emerging secular biomedical paradigm. ${ }^{2}$ The same is true today. In the 1970s, Primary Health Care (PHC) offered a much needed critique to a purely biomedical model, a critique influenced by the Christian Medical Commission ${ }^{3}$ and vigorously adopted by MAP International. ${ }^{4}$ However, a major tenet of this approach, community participation, is not a distinctly Christian notion; it draws more from democratic and socialist political notions. Current needed modifications to this PHC approach, an ecological paradigm $^{4}$ and a systems approach ${ }^{5}$, are likewise drawn from the academy, not from Christian reflection. Then on the opposite side of the "socialist" PHC approaches are the individualist

Nov 2015. Christian Journal for Global Health, 2(2):16-19. 
free-market development notions, not distinctly Christian, used especially by indigenous Pentecostal churches for social ministries of all kinds, including health care. ${ }^{6}$

But are there distinctive Christian approaches? At the close of World War II in France, Jacques Ellul proposed to address the question, "What part should [the Christian] play in the life of the world?"7 - a haunting question in a country compromised and nearly destroyed by the Nazi regime. The question is equally relevant today for Christian global health workers. Ellul begins his response this way:

... we need to remember that the Christian must not act in exactly the same way as everyone else. He has a part to play in this world which no one else can possibly fulfill. He is not asked to look at the various movements which men have started, choose those which seem 'good,' and support them ... He is charged with a mission of which the natural man can have no idea; yet in reality this mission is decisive for the actions of men.

$\mathrm{He}$ then presents three specific Biblical functions of Christian engagement in the world:

- To be the salt of the earth: "The fact that Christians are, in their lives, the 'salt of the earth,' does far more for the preservation of the world than external action."

- To be the light of the world: "The Christian ... reveals to the world the truth about its condition."

- To be sheep in the midst of wolves: "Christians must . . . offer the daily sacrifice of their lives, which is united with the sacrifice of Jesus Christ."

In all of these functions, Ellul says, we are to be "signs" of the reality of God's action in the world. "Technical work" needs to be done, he says, "but this work is done by everybody, and it has no meaning unless it is guided, accompanied, and sustained by another work that only the Christian can do, and that he often does not do." The rest of Ellul's book is an exploration of what this involves.

Ironically - or perhaps understandably - it is a secular study of "humanitarian reason" that most clearly exposes some of what "only the Christian can do." The physician-anthropologist Didier Fassin, in the conclusion to his example-filled study, considers the foundations of this humanitarianism. ${ }^{8}$ For modern western societies, he says, engagement with the world is built around how we deal with suffering:

... while the spectacle of suffering has disappeared completely from the public places where the physical punishment inflicted on criminals was previously exhibited, the representation of suffering through images and narratives has become increasingly commonplace in the public sphere, not only in the media . . . but also in the political arena, where it furnishes an effective justification for action.

Think of famine, AIDS, and Ebola. He then probes the origins of this focus on suffering:

This fascination with suffering also derives from a Christian genealogy ... [T]he valorization of suffering as the basic human experience is closely linked to the passion of Christ redeeming the original sin ... The singular feature of Christianity in this respect is that it turns suffering into redemption. However, modernity marks a turning point in this genealogy of redemptive suffering, both in literature and in politics ... With the entry of suffering into politics, we might say that salvation emanates not through the passion one endures, but through the compassion one feels.

Nov 2015. Christian Journal for Global Health, 2(2): 16-19. 
Humanitarianism has sanitized suffering. This is not the daily sacrifice of our lives, united with the suffering of Christ, of which Ellul wrote. It is not the role of a sheep, but of one who feels sorry for sheep. "In Western societies," writes Fassin, "the paradigm of romantic engagement with the world has thus shifted from the figure of the volunteer risking his or her life alongside liberation movements to the figure of the humanitarian saving lives in spaces set apart from the fighting ...., spaces he describes a bit later as "protected corridors of aid."

Or, in a more disturbing example, this scene from the recent movie American Sniper: At a dinner table discussion with his children, one of whom will become the sniper, the father explains to them that there are three types of people in the world: sheep, wolves, and sheepdogs. Sheep, he says, are people who prefer to believe that evil doesn't exist in the world, and if evil presented itself on their doorstep, they wouldn't know how to protect themselves. Wolves are predators who prey on the weak. And sheepdogs are rare: they "are blessed with the gift of aggression" and feel an overwhelming need to protect the flock against wolves. The father was clear: "We aren't raising any sheep in this family ... . We protect our own." It is the most frightening scene in the movie.

There is no longer any conceptual room for, any understanding of, being sent as sheep in the midst of wolves. "Yet" (Ellul again):

The world cannot live without this living witness of sacrifice. That is why it is essential that Christians should be very careful not to be 'wolves' in the spiritual sense - that is, people who try to dominate others. Christians must accept the domination of other people, and offer the daily sacrifice of their lives, which is united with the sacrifice of Jesus Christ.
The world cannot live without this kind of sacrifice, and there is something in our humanitarian Western societies that knows this, that remembers this. We knew that Mother Theresa did nothing to prolong the lives of dying people in Calcutta, but we still gave her the Nobel Peace Prize. We knew that three missionaries contracting Ebola did nothing to stop the epidemic, but their story still resonates with something dormant in us. Though it makes no scientific sense, something deep within us knows that the world cannot live without this kind of sacrifice. But because it makes no scientific sense, we spend our effort promoting sheepdogs and protected corridors of aid - until a missionary gets Ebola.

Our problem as Christians is that there can be no algorithm for knowing how and when to be preserving salt, revealing light, and especially sheep in the midst of wolves. Ellul admits that we cannot change the world, yet we cannot live with it the way it is. He calls this a "very painful and very uncomfortable situation," yet "we must accept this tension and live in it." And, he says later, "see how God's will of preservation can act in this given situation." The first sacrifice we must make is letting go of the need to control and the assurance of results and of change. It is God's will of preservation, not ours.

Beyond this, there is no formula. For my friend Tom Little, the sacrifice of his life was literal. A Christian optometrist who had worked for over 30 years in Afghanistan, I doubt that he saw living in another culture as a sacrifice. The Tom I knew in college didn't share the upwardly mobile dreams of most students, but he did feel passionate about getting health care to those in rural Afghanistan - and when he and 9 other global health workers were killed by the Taliban on the way back from an eye camp in 2010 , they died as sheep in the midst of wolves.

For my wife and me, the sacrifice is far more mundane. Like Tom, we do not find living in Africa for nearly 30 years to be a sacrifice. But as we have 
moved from working in mission hospitals under mission agencies to working for a public university in a government hospital, we begin to feel more like sheep among wolves. We feel what other staff, and certainly the patients, must feel: in a place where supplies are inadequate, morale is low, and the corruption of politicians sets the example for institutional leadership, services are woefully inadequate. We miss the relative efficiency of mission hospitals, but they have become places to which many patients can no longer go because they cannot afford them. Working for the government is certainly frustrating, but at least we are working with patients who have no other option; at least our view of reality becomes clearer.

We must continue the search for "best practices" for Christian global health workers. We must continue to name our foundations and debate approaches and gather evidence, for we all need to get up in the morning and $d o$ something. Being salt, light, and sheep among wolves is not a job description; it is who we are, not what we do. But unless we are being what only Christians can be, we will have nothing distinctive to offer global health and will play no role in the enlightenment and preservation of the world.

\section{References}

1. Strand MA, Cole MA. Framing the role of the faith community in global health. CJGH, 1(2):7-15.

http://dx.doi.org/10.15566/cjgh.v1i2.19
2. Downing R. The gospel of science. CJGH 2(1):43-8. http://dx.doi.org/10.15566/cjgh.v2i1.25

3. Litsios S. The Christian Medical Commission and the development of the World Health Organization's primary health care approach. Am J Public Health. 2004

Nov;94(11):1884-93.

http://dx.doi.org/10.2105/AJPH.94.11.1884

4. DeAngulo JM, Losada LS. Health paradigm shifts in the 20th century. CJGH.2(1):49-58.

http://dx.doi.org/10.15566/cjgh.v2i1.37

5. Swanson RC, Thacker BJ. Systems thinking in shortterm health missions: a conceptual introduction and consideration of implications for practice. CJGH 2(1):722. http://dx.doi.org/10.15566/cjgh.v2i1.50

6. Myers BL. Progressive Pentecostalism, development, and Christian development NGOs: a challenge and an opportunity. Int BMs Res.1915 Jul;39(3):115-20.

7. Ellul J. The Presence of the Kingdom. $1^{\text {st }}$ edition. New York: Seabury Press; 1967. [First edition in French 1948] [All quotes from the first chapter, "The Christian in the World."]

8. Fassin D. Humanitarian Reason: A Moral History of the Present. Berkeley: University of California Press; 2012. [All quotes from the Conclusion]

Peer Reviewed

Competing Interests: None declared.

Correspondence: Raymond Downing, Moi University School of Medicine, Kenya. armdown2001@yahoo.com

Cite this article as: Downing R. Should Christian global health be distinctive? A Reflection. Christian Journal for Global Health (Nov 2015), 2(2):16-19.

(C) Downing $\mathrm{R}$ This is an open-access article distributed under the terms of the Creative Commons Attribution License, which permits unrestricted use, distribution, and reproduction in any medium, provided the original author and source are properly cited. To view a copy of the license, visit http://creativecommons.org/licenses/by/3.0/

\section{www.cjgh.org}

Nov 2015. Christian Journal for Global Health, 2(2): 16-19. 